\title{
KNOWLEDGE MANAGEMENT SYSTEM BERBASIS WEB TENTANG BUDIDAYA HIDROPONIK UNTUK MENDUKUNG SMART SOCIETY
}

\author{
Ariq Cahya Wardhana ${ }^{1}$, Yani Nurhadryani², Sri Wahjuni ${ }^{3}$ \\ 1,2,3 Departemen Ilmu Komputer, FMIPA, Institut Pertanian Bogor \\ ${ }^{1}$ Prodi S1 Rekayasa Perangkat Lunak, Fakultas Informatika, Institut Teknologi Telkom Purwokerto \\ Email: 19ariq@ittelkom-pwt.ac.id, ${ }^{2}$ yani_nurhadryani@apps.ipb.ac.id, ${ }^{3}$ my_juni04@apps.ipb.ac.id \\ *Penulis Korespondensi
}

(Naskah masuk: 11 Juli 2019, diterima untuk diterbitkan: 27 April 2020)

\begin{abstract}
Abstrak
Meningkatnya jumlah populasi penduduk di Indonesia berdampak pada terbatasnya luas wilayah pertanian di Kota Bogor yang mengakibatkan ancaman produksi pertanian karena konversi lahan persawahan sebesar $88,12 \%$ menjadi perumahan dan kebun. Solusi sistem produksi pertanian dengan terbatasnya lahan salah satunya adalah hidroponik. Untuk meningkatkan pengetahuan budidaya hidroponik dan memudahkan akses fasilitas belajar digital sebagai bagian penting dari rencana pemerintah Kota Bogor yaitu smart society diperlukan dukungan teknologi informasi. Penelitian ini bertujuan mengembangkan Knowledge Management System (KMS) budidaya hidroponik dengan mengadopsi metode Knowledge Management Life Cycle melalui identifikasi pengetahuan tacit maupun explicit dari komunitas hidroponik. Proses menangkap pengetahuan berorientasi pada seluruh proses budidaya sayuran hidroponik dengan menggunakan bibit yang siap tanam. Knowledge map digunakan untuk kodifikasi pengetahuan menghasilkan 34 pengetahuan explicit berupa media interaktif video maupun dokumen yang dapat digunakan oleh pengguna. Implementasi sistem menggunakan aplikasi berbasis Web dengan pendekatan object oriented yang sudah diuji oleh pakar dan semua fungsi berjalan dengan baik. Sistem ini memiliki fitur klasifikasi KMS yaitu knowledge capture, knowledge sharing, serta knowledge discovery.
\end{abstract}

Kata kunci: hidroponik, smart society, knowledge management system, knowledge management life cycle

\section{WEB-BASED KNOWLEDGE MANAGEMENT SYSTEM CONCERNING HYDROPONIC CULTIVATION TO SUPPORT SMART SOCIETY}

\begin{abstract}
The increasing number of populations in Indonesia has an impact on the limited area in Bogor, which has resulted in the threat of agricultural production because of the conversion of $88.12 \%$ of paddy fields to housing and gardens. A solution to agricultural production systems with limited land, one of which is hydroponics. Facilitate access to digital learning facilities as an essential part of the plan of the Bogor City government, namely smart society, information technology support is needed as a means of sharing hydroponic cultivation knowledge. Based on this, we developed a knowledge management system (KMS) adopting the Knowledge Management Life Cycle method by identifying tacit and explicit knowledge from the hydroponic community. The process of capturing knowledge is oriented to the whole process of hydroponic vegetable cultivation by using seeds that are ready for planting. Knowledge map is used for codification of knowledge that produces 34 explicit knowledge in the form of interactive media in the form of videos and documents that can be used by user. The output generated from this study is KMS was implemented using Web-based applications with an object-oriented approach that has been tested by experts with system functions is working and has KMS classification features, namely knowledge capture, knowledge sharing, and knowledge discovery.
\end{abstract}

Keywords: hydroponics, smart society, knowledge management system, knowledge management life cycle

\section{PENDAHULUAN}

Meningkatnya jumlah populasi masyarakat di Indonesia, tentu berdampak pada kondisi perkotaan. World bank melansir, Indonesia mengalami transformasi perpindahan masyarakat pedesaan ke kota terbesar di asia dengan tingkat pertumbuhan 4,1\% per tahun dan diprediksi pada tahun 2025 sebesar 68\% masyarakat di Indonesia hidup di perkotaan (World Bank 2016). Seiring meningginya tingkat pertumbuhan jumlah penduduk, kota akan cenderung tidak teratur sehingga menimbulkan 
masalah baru seperti kelangkaan sumber daya dan infrastuktur kota (Chourabi et al. 2012). Kota Bogor juga mengalami dampaknya dengan meningkatnya urbanisasi sebesar $1.6 \%$ dan semakin terbatasnya wilayah (Diskominfostandi 2017a). Sejak tahun 2017 pemerintah Kota Bogor melakukan perencanaan implementasi smart city sebagai solusi mengatasi masalah tersebut. Salah satu dimensinya adalah smart society.

Smart society menggambarkan masyarakat yang cerdas dimana kualitas, efisiensi, produktivitas, dan daya saing masyarakat meningkat secara dramatis melalui penggunaan TI secara luas (Njeru et al. 2017). Smart society merupakan dimensi yang membahas tentang manusia sebagai unsur utama sebuah kota dan setiap individu dalam masyarakat disediakan fasilitas belajar secara digital untuk mendukung akses pendidikan (Citiasia 2015). Terdapat tiga elemen utama untuk mewujudkan tujuan smart society yaitu ekosistem pembelajaran/learning, komunitas warga/community dan sistem keamanan/security (Diskominfostandi 2017b). Interaksi antar masyarakat akan semakin kuat dengan tersedianya media teknologi yang bertujuan menciptakan masyarakat produktif, komunikatif, interaktif serta memiliki digital literacy yang tinggi (Levy dan Wong 2014).

Kota Bogor dengan kondisi tidak dapat menambah luasan wilayah, tidak dapat terus membangun gedung dan jalan (Diskominfostandi 2017a). Terbatasnya luas wilayah Kota Bogor memicu konversi lahan persawahan sebesar $88,12 \%$ menjadi perumahan dan kebun yang mengakibatkan ancaman terhadap produksi pertanian (Hidayati et al. 2017). Pertanian urban secara vertikultur, cocok tanam terasering, dan hidroponik merupakan sistem produksi pangan yang bertujuan menyokong pembangunan berkelanjutan dalam menghadapi keterbatasan lahan (Ula et al. 2015). Pemerintah kota Bogor melalui dinas pertanian bekerja sama dengan komunitas mulai memberikan pelatihan pertanian urban secara hidroponik pada beberapa kelompok wanita tani (Metropolitan 2018). Pelatihan tersebut sebagai pembelajaran masyarakat dalam gerakan pertanian di perkotaan yang mengacu pada misi pertama rencana strategis dinas pertanian Kota Bogor yaitu peningkatan kemampuan sumberdaya manusia pertanian terutama petani (Distani 2014). Sedangkan untuk mendukung smart society pada elemen ekosistem pembelajaran, khususnya pembelajaran pertanian urban diperlukan penggunaan teknologi informasi. Salah satunya dapat melalui pengembangan knowledge management system untuk membantu mendukung meningkatkan pengetahuan masyarakat perkotaan.

Knowledge management system (KMS) merupakan sistem yang memfasilitasi penggunaan kembali pengetahuan melalui menangkap, menyimpan, mencari, dan membagi pengetahuan (Hajric 2018). Sedangkan peran manajemen pengetahuan itu sendiri merupakan pusat informasi dan pengetahuan manusia yang dibutuhkan untuk membuat kota menjadi lebih cerdas (Negre et al. 2015). Manajemen pengetahuan bertujuan mengidentifikasi, memanfaatkan, dan menghasilkan berbagai inovasi melalui identifkasi pengetahuan (Munir 2011). Selain menyimpan pengetahuan pertanian urban, penggunaan KMS dapat berperan sebagai sarana bagi petani yang diberdayakan untuk mencari pengetahuan berbasis teknologi informasi sebagai salah satu proses pembelajaran secara digital.

Tujuan penelitian ini merupakan mengembangkan KMS budidaya hidroponik melalui identifikasi pengetahuan baik tacit (pengetahuan yang belum digali) maupun explicit (pengetahuan yang terdokumentasi, tersimpan, atau dibukukan), menyimpan pengetahuan tersebut untuk dijadikan informasi atau referensi yang bermanfaat bagi masyarakat untuk mendukung akses pembelajaran digital pada smart society. Pengembangan KMS budidaya hidroponik ini dilakukan menggunakan metodologi Knowledge Management System Life Cycle (Awad dan Ghaziri 2010).

\section{HIDROPONIK DI KOTA BOGOR}

Pertanian urban secara vertikultur, cocok tanam terasering, dan hidroponik merupakan sistem produksi pangan yang bertujuan menyokong pembangunan berkelanjutan dalam menghadapi keterbatasan lahan (Ula et al. 2015). Pemerintah kota Bogor melalui dinas pertanian bekerja sama dengan komunitas mulai memberikan pelatihan pertanian urban secara hidroponik pada beberapa kelompok wanita tani (Metropolitan 2018).

Pelatihan tersebut sebagai pembelajaran masyarakat dalam gerakan pertanian di perkotaan yang mengacu pada misi pertama rencana strategis dinas pertanian Kota Bogor yaitu peningkatan kemampuan sumberdaya manusia pertanian terutama petani (Distani 2014). Pelatihan tersebut melibatkan salah satu komunitas hidroponik di Kota Bogor yaitu Komunitas Hidroponik Bogor Raya (Kohibora). Kelompok wanita tani dari perwakilan setiap kecamatan sebagai peserta pelatihan sedangkan kohibora melatih kelompok tersebut dalam mengembangkan budidaya hidroponik. Jumlah anggota komunitas saat ini yang terdata berjumlah 150 orang.

Proses budidaya hidroponik secara umum memiliki beberapa tahapan yaitu instalasi hidroponik, membuat larutan nutrisi, mempersiapkan tanaman, pemeliharaan tanaman (Swastika et al. 2017). Obyek pengetahuan awal yang diambil yaitu pengetahuan budidaya sayuran hidroponik. Pemilihan sayuran karena diperlukan mengacu pada program direktorat jenderal holtikultura tentang peningkatan produksi dan budidaya holtikultura melalui bimbingan teknis budidaya untuk kelompok wanita dalam memanfaatkan pekarangan. 


\section{SMART SOCIETY}

Kota Bogor merancang beberapa dimensi yang mendukung smart city salah satunya adalah smart society (Diskominfostandi 2017b). Smart society menggambarkan masyarakat yang cerdas dimana kualitas, efisiensi, produktivitas, dan daya saing masyarakat meningkat secara dramatis melalui penggunaan TI secara luas (Njeru et al. 2017). Smart society merupakan dimensi yang berorientasi pada manusia dan setiap individu harus diberikan fasilitas belajar digital untuk mendukung akses pendidikan (Citiasia 2015).

Interaksi antar masyarakat akan semakin kuat dengan tersedianya media teknologi yang bertujuan menciptakan masyarakat produktif, komunikatif, interaktif serta memiliki digital literacy yang tinggi (Levy dan Wong 2014). Karakteristik dari smart society salah satunya edukasi pengetahuan yaitu partisipasi aktif masyarakat dalam proses produksi pengetahuan seperti pengumpulan pengetahuan secara kolektif (Njeru et al. 2017).

\section{KNOWLEDGE MANAGEMENT SYSTEM}

Knowledge Management System (KMS) merupakan aplikasi web yang mampu menyimpan dan mengambil pengetahuan, meningkatkan kolaborasi,menempatkan sumber pengetahuan, menambah repositori untuk pengetahuan tersembunyi, menangkap dan menggunakan pengetahuan (Jia dan Li 2016). Menurut Awad dan Ghaziri (2010), terdapat tiga klasifikasi fitur yang menunjukan bahwa sistem tersebut merupakan sistem manajemen pengetahuan yaitu:

1. Knowledge discovery yaitu adanya sistem untuk menemukan pengetahuan. Modul ini merupakan sebuah alat untuk para pengguna menemukan pengetahuan-pengetahuan yang dibutuhkan. Bisa berupa mesin pencari yang dapat digunakan untuk menemukan sebuah artikel.

2. Knowledge capture yaitu fitur menangkap pengetahuan. Modul dari sistem yang berfungsi untuk menangkap pengetahuan yang baru yang belum ada dalam sistem yang berjalan bisa berupa entry data sebuah pengetahuan baru yang berhasil ditangkap.

3. Knowledge sharing yaitu adanya sistem untuk berbagi pengetahuan. Modul dari aplikasi dimana aplikasi menyediakan akses untuk dapat mengambil pengetahuan.

Pengetahuan menurut Nonaka dibagi kedalam 2 jenis yaitu tacit knowledge dan explicit knowledge (Semertzaki 2011). Tacit knowledge merupakan pengetahuan yang berasal dari pengalaman bersifat subyektif, kognitif dan pembelajaran. Explicit knowledge yaitu pengetahuan berbentuk dokumen bersifat objektif, rasional, teknis dan sifatnya yang independen.

Pengetahuan yang ditangkap dilakukan proses dokumentasi. Proses tersebut akan mengatur, mengkategorikan, mengindeks pengetahuan agar mudah diakses. Menurut Awad Ghaziri (2010) terdapat beberapa prosedur yang dapat digunakan untuk mendukung proses tersebut, yaitu:

1. Knowledge Map merupakan kejadian saling terhubung antara satu dengan lainnya pada suatu rangkaian proses yang dijabarkan melalui representasi visual pengetahuan.

2. Decision Tree merupakan titik maupun garis yang menunjukkan kondisi atau tindakan dengan berbentuk pohon keputusan.

3. Case-Based Reasoning merupakan teknik mencari kasus lama yang sesuai untuk memecahkan kasus baru. Dokumentasi kasus lama diklasifikasikan sehingga jika ada kasus baru bisa dicari berdasarkan kemiripannya.

Pada penelitian ini sistem yang dikembangkan mengacu pada tiga klasifikasi fitur utama KMS. Proses kodifikasi pengetahuan menggunakan knowledge map yang bertujuan memetakan pengetahuan budidaya hidroponik yang masih belum terindeks secara baik melalui representasi visual agar secara mudah dipahami dan digunakan kembali pengetahuan tersebut.

\section{METODE PENELITIAN}

Metode Knowledge Management System Life Cycle (KMSLC) oleh Awad dan Ghaziri (2010) memiliki delapan tahapan seperti pada Gambar 1. Namun, pada penelitian ini hanya digunakan lima tahapan sampai pada tahap verifikasi dan validasi.

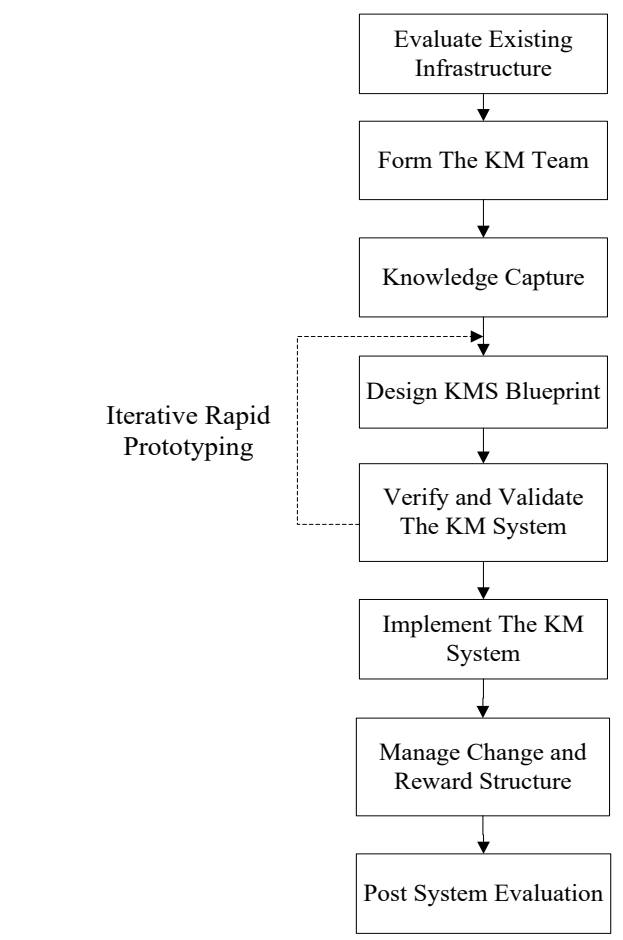

Gambar 1. Metode knowledge management system lifecycle (Awad dan Ghaziri 2010) 
Lima tahapan KMSLC yang digunakan pada penelitian ini, yaitu:

1. Mengevaluasi Infrastruktur

Tahap ini dilakukan evaluasi infrastruktur secara perangkat lunak, sumber daya manusia dan pengetahuan. Pada evaluasi perangkat lunak dilakukan identifikasi aplikasi apa saja yang sudah digunakan pada proses berbagi pengetahuan hidroponik. Selanjutnya evaluasi sumber daya manusia merupakan pemilihan pakar hidroponik di komunitas untuk dijadikan sumber pengetahuan. Kemudian evaluasi pengetahuan bertujuan untuk mendapatkan pengetahuan apa saja yang tersedia di komunitas.

2. Membentuk Tim Knowledge Management Tahap ini dilakukan pembentukan tim knowledge management yang bertugas menunjang pengembangan Knowledge Management System budidaya hidroponik. Pembentukan tim dilakukan melalui identifikasi stakeholder yang diperlukan kemudian mereka dilibatkan dalam pengembangan KMS.

3. Menangkap Knowledge

Proses menangkap pengetahuan dilakukan dengan teknik On-Site Observation yaitu mengamati, mencatat, merekam dan menerjemahkan proses budidaya hidroponik serta menggunakan teknik wawancara untuk menangkap pengetahuan dari pakar.

4. Mendesain Blueprint Knowledge Management System

Melakukan proses perancangan kodifikasi pengetahuan menggunakan knowledge map yang bertujuan untuk representasi visual dari pengetahuan. Kemudian melakukan perancangan aplikasi dengan pendekatan berorientasi obyek menggunakan Unified Modeling Language (UML). Melakukan proses konversi rancangan kedalam kode program dalam bentuk aplikasi berbasis $W e b$.

5. Verifikasi dan Validasi Knowledge Management System

Melakukan knowledge testing yaitu pengujian logikal dan pengujian penerimaan pengguna (Awad dan Ghaziri 2010). Pengujian logikal dilakukan verifikasi hasil kodifikasi pengetahuan melalui pakar sedangkan pengujian penerimaan pengguna digunakan metode blackbox testing pada pakar untuk menguji fungsi aplikasi dengan melihat keluaran data yang dihasilkan.

\section{HASIL DAN PEMBAHASAN}

\subsection{Hasil Evaluasi Infrastruktur}

Hasil analisa infrastruktur perangkat lunak, terdapat beberapa perangkat lunak yang biasa digunakan oleh komunitas yaitu website komunitas sebagai sarana informasi berita dan aplikasi Whatsapp group sebagai sarana komunikasi.
Hasil analisa infrastruktur sumber daya manusia melalui wawancara terhadap ketua komunitas dipilih beberapa anggota komunitas yang ditunjuk sebagai sumber pengetahuan budidaya hidroponik seperti pada Tabel 1.

Tabel 1. Infrastruktur Sumber Daya Manusia (SDM)

\begin{tabular}{ll}
\hline \multicolumn{1}{c}{ SDM } & \multicolumn{1}{c}{ Kepakaran } \\
\hline Dra Hj Hanny Nabila M.Si & Organisasi Hidroponik \\
Ir Agus Gozali M.SC & Hama dan Penyakit \\
Herawaty Ayung & Hidroponik \\
Prabani Setiohindrianto & Pemeliharaan, Nutrisi dan \\
& Sistem Hidroponik \\
\hline
\end{tabular}

Hasil analisa infrastruktur pengetahuan di komunitas terdapat 17 pengetahuan dasar untuk pemula yang ada berkaitan dengan budidaya sayuran hidroponik. Modul pengetahuan explicit berbentuk softcopy maupun hardcopy didapatkan dari Ibu Hanny Nabila dan Bapak Agus Gozali. Modul pengetahuan tacit diambil dari pengalaman pakar. Hasil analisa infrastruktur pengetahuan terdapat pada Tabel 2.

Tabel 2. Infrastruktur Pengetahuan

\begin{tabular}{|c|c|c|c|}
\hline No & Pengetahuan & Tacit & Explicit \\
\hline 1 & Modul hidroponik untuk pemula & & $\sqrt{ }$ \\
\hline 2 & $\begin{array}{l}\text { Modul alternatif pengganti } \\
\text { rockwool }\end{array}$ & & $\sqrt{ }$ \\
\hline 3 & Modul bio pestisida & & $\sqrt{ }$ \\
\hline 4 & $\begin{array}{l}\text { Modul cara menentukan ukuran } \\
\text { pompa }\end{array}$ & & $\sqrt{ }$ \\
\hline 5 & $\begin{array}{l}\text { Modul efisiensi energi dan sarana } \\
\text { produksi }\end{array}$ & & $\sqrt{ }$ \\
\hline 6 & Modul hidroponik murah & & $\sqrt{ }$ \\
\hline 7 & Modul kalibrasi pH meter & & $\sqrt{ }$ \\
\hline 8 & $\begin{array}{l}\text { Modul cara menentukan ukuran } \\
\text { pompa }\end{array}$ & & $\sqrt{ }$ \\
\hline 9 & $\begin{array}{l}\text { Modul mengatasi kendala dalam } \\
\text { hidroponik }\end{array}$ & & $\sqrt{ }$ \\
\hline 10 & Modul optimasi input nutrisi & & $\sqrt{ }$ \\
\hline 11 & $\begin{array}{l}\text { Modul optimasi pertumbuhan } \\
\text { tanaman melalui pengaturan } \mathrm{pH}\end{array}$ & & $\sqrt{ }$ \\
\hline 12 & $\begin{array}{l}\text { Modul pengendalian hama dan } \\
\text { penyakit tanaman }\end{array}$ & & $\sqrt{ }$ \\
\hline 13 & Modul TDS-EC Meter & & $\sqrt{ }$ \\
\hline 14 & Pengalaman media tanam & $\sqrt{ }$ & \\
\hline 15 & $\begin{array}{l}\text { Pengalaman instalasi sistem } \\
\text { hidroponik }\end{array}$ & $\sqrt{ }$ & \\
\hline 16 & Pengalaman penanganan hama & $\sqrt{ }$ & \\
\hline 17 & Pengalaman penggunaan nutrisi & $\sqrt{ }$ & \\
\hline
\end{tabular}

\subsection{Hasil Membentuk Tim Knowledge Management}

Proses ini dilakukan pembentukan tim knowledge management (KM) agar dapat mengidentifikasi sumber daya atau stakeholder yang diperlukan. Tim KM ini terdiri dari pihak peneliti maupun komunitas seperti pada Tabel 3 yang terbagi menjadi pakar hidroponik, pengembang KM, anggota dan umum. 
Tabel 3. Tim Knowledge Management

\begin{tabular}{|c|c|c|}
\hline Jabatan & Sumber Daya & Keterangan \\
\hline $\begin{array}{l}\text { Pakar } \\
\text { Hidroponik }\end{array}$ & $\begin{array}{l}\text { Dra Hj Hanny } \\
\text { Nabila M.Si, Ir } \\
\text { Agus Gozali } \\
\text { M.SC, } \\
\text { Herawaty } \\
\text { Ayung, Prabani } \\
\text { Setiohindrianto }\end{array}$ & $\begin{array}{l}\text { Merupakan pakar yang } \\
\text { menjadi sumber } \\
\text { pengetahuan hidroponik, } \\
\text { mereka terdiri dari } \\
\text { pengurus maupun } \\
\text { anggota komunitas. }\end{array}$ \\
\hline $\begin{array}{l}\text { Pengembang } \\
\text { KM }\end{array}$ & $\begin{array}{l}\text { Ariq Cahya } \\
\text { Wardhana } \\
\text { Skom, Yani } \\
\text { Nurhadryani } \\
\text { SSi MT PhD, } \\
\text { Dr Ir Sri } \\
\text { Wahjuni MT }\end{array}$ & $\begin{array}{l}\text { Orang yang } \\
\text { mengembangkan sistem } \\
\text { KMS budidaya } \\
\text { hidroponik. }\end{array}$ \\
\hline Anggota & $\begin{array}{l}\text { Anggota } \\
\text { komunitas atau } \\
\text { masyarakat } \\
\text { umum }\end{array}$ & $\begin{array}{l}\text { Orang yang membantu } \\
\text { pengambilan } \\
\text { pengetahuan tentang } \\
\text { budidaya hidroponik } \\
\text { yang telah terdata sebagai } \\
\text { anggota komunitas diluar } \\
\text { pakar. }\end{array}$ \\
\hline Umum & $\begin{array}{l}\text { Masyarakat } \\
\text { umum }\end{array}$ & $\begin{array}{l}\text { Orang yang membantu } \\
\text { pengambilan } \\
\text { pengetahuan budidaya } \\
\text { hidroponik dan bukan } \\
\text { sebagai anggota } \\
\text { komunitas. }\end{array}$ \\
\hline
\end{tabular}

\subsection{Menangkap Knowledge}

Mengacu pada Swastika et al. (2017), proses budidaya sayuran hidroponik terdiri dari 4 tahapan yaitu instalasi hidroponik, membuat larutan nutrisi, persiapan tanaman, dan pemeliharaan tanaman. Pemetaan kebutuhan pengetahuan untuk mendukung tahapan budidaya tersebut dapat dilihat di Tabel 4 yang mengacu pada ketersediaan infrastruktur pengetahuan.

Pada tahap menangkap pengetahuan explicit diperoleh sumber pengetahuan yang berjumlah 13 pengetahuan explicit yang berasal dari dokumen modul pelatihan hidroponik seperti pada Tabel 2 . Sedangkan pengetahuan tacit didapatkan melalui teknik On-Site Observation melalui rekaman video secara langsung dilapangan.

Tabel 4. Ketersediaan Pengetahuan Berdasarkan Kebutuhan

\begin{tabular}{|c|c|c|}
\hline & $\begin{array}{l}\text { p Budidaya } \\
\text { oponik }\end{array}$ & Ketersediaan Pengetahuan \\
\hline 1. & $\begin{array}{l}\text { Instalasi } \\
\text { hidroponik }\end{array}$ & $\begin{array}{ll}- & \text { Menentukan ukuran pompa } \\
\text { - } & \text { Pengalaman instalasi sistem } \\
& \text { hidroponik }\end{array}$ \\
\hline 2. & $\begin{array}{l}\text { Membuat } \\
\text { larutan nutrisi }\end{array}$ & $\begin{array}{ll}\text { - } & \text { Pengalaman mencampur } \\
& \text { nutrisi AB mix } \\
\text { - } & \text { Pengaturan optimasi input } \\
\text { nutrisi dan } \mathrm{pH} \\
\text { - } & \text { Pengetahuan pengunaan TDS- } \\
& \text { EC Meter dan } \mathrm{pH} \text { meter }\end{array}$ \\
\hline 3. & $\begin{array}{l}\text { Persiapan } \\
\text { tanaman }\end{array}$ & $\begin{array}{ll}\text { - } & \text { Penyiapan media tanam } \\
\text { - } & \text { Alternatif pengganti rockwool }\end{array}$ \\
\hline 4 & $\begin{array}{l}\text { Pemeliharaan } \\
\text { tanaman }\end{array}$ & $\begin{array}{ll}\text { - } & \text { Pengalaman penanganan hama } \\
\text { - } & \text { Penggunaan bio pestisida }\end{array}$ \\
\hline
\end{tabular}

Pengetahuan tacit yang diambil untuk melengkapi kebutuhan pengetahuan terdiri dari pengalaman budidaya sayuran hidroponik seperti persiapan media tanam, mengatur nutrisi, instalasi sistem serta penanganan hama. Pada Gambar 2 merupakan proses pengambilan pengetahuan bersama pakar komunitas yang bertujuan mendapatkan pengetahuan tacit berupa pengalaman berhidroponik berbentuk video interaktif.

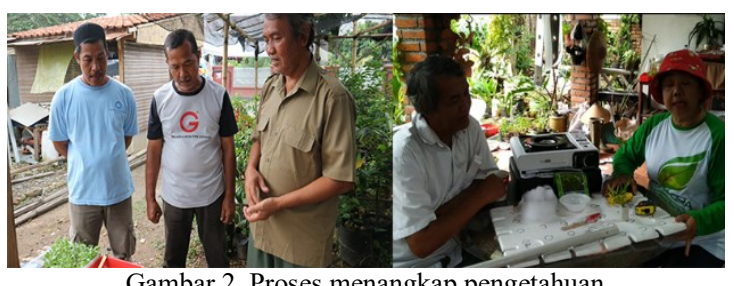

Gambar 2. Proses menangkap pengetahuan

\subsection{Mendesain Blueprint Knowledge Management System}

Perancangan kodifikasi pengetahuan yang dibangun menggunakan knowledge map untuk menggambarkan peta pengetahuan seperti pada Gambar 3. Peta pengetahuan didapatkan dari diskusi bersama pakar untuk melengkapi kebutuhan pengetahuan sesuai pada tahapan budidaya sayuran hidroponik yang terdiri dari 4 kategori utama yaitu pengetahuan dasar, hama dan penyakit, sistem hidroponik, dan hasil panen.

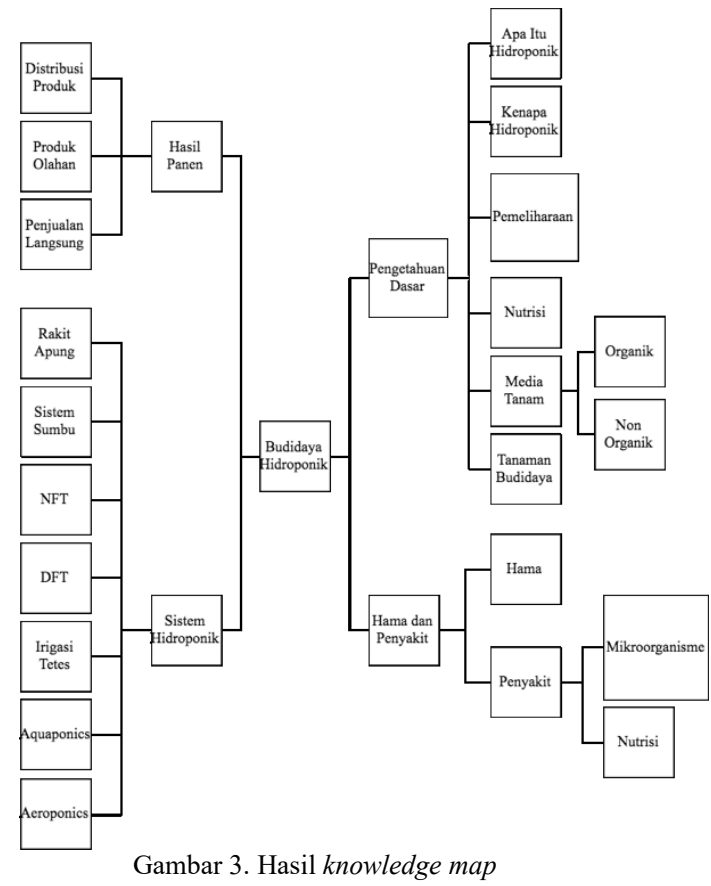

Selanjutnya dilakukan pemetaan data hasil proses menangkap knowledge pada tahap sebelumnya berdasarkan rancangan knowledge map. Didapatkan 34 pengetahuan explicit yang siap disimpan pada database yaitu 14 data berbentuk video interaktif, 5 
dokumen berformat pptx, dan 15 dokumen berbentuk pdf.

Langkah berikutnya adalah melakukan perancangan kebutuhan fungsional aplikasi berdasarkan aktor yang terlibat dalam lingkungan sistem seperti pada Gambar 4. Melalui use case diagram terdapat empat aktor yaitu anggota, pakar, umum dan admin. pengetahuan tanpa mendaftar sebagai pengguna. Admin memiliki fitur yang dapat mengelola data pengguna dan mengelola profil.

Dari seluruh kebutuhan fungsional sistem yang mewakili fitur standar klasifikasi KMS terdapat pada fitur mencari pengetahuan sebagai knowledge discovery yaitu fitur yang memudahkan pengguna dalam mencari pengetahuan tersimpan dengan

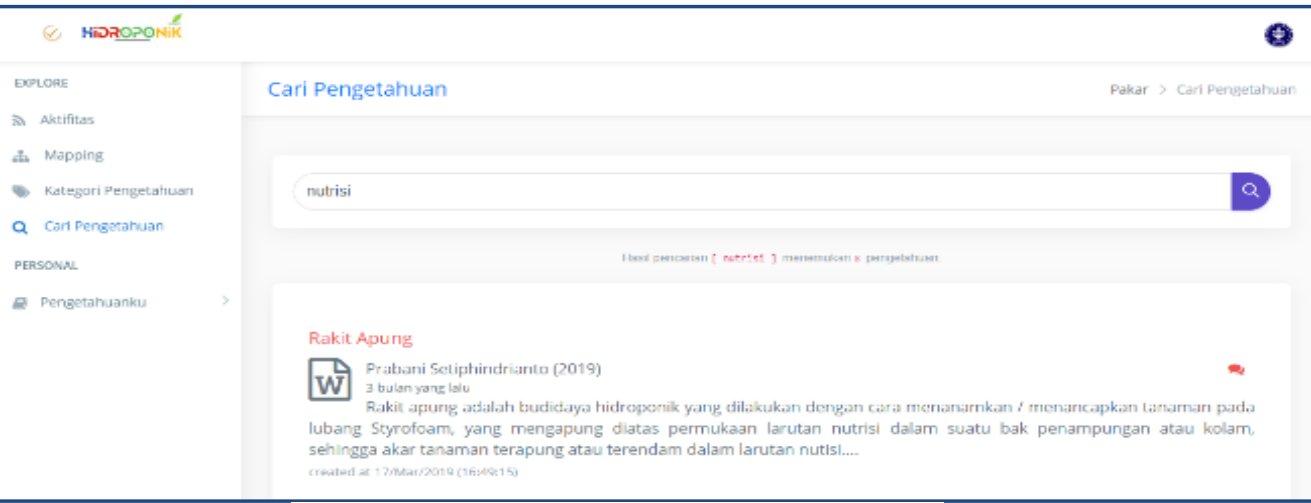

Gambar 6. Halaman mencari pengetahuan

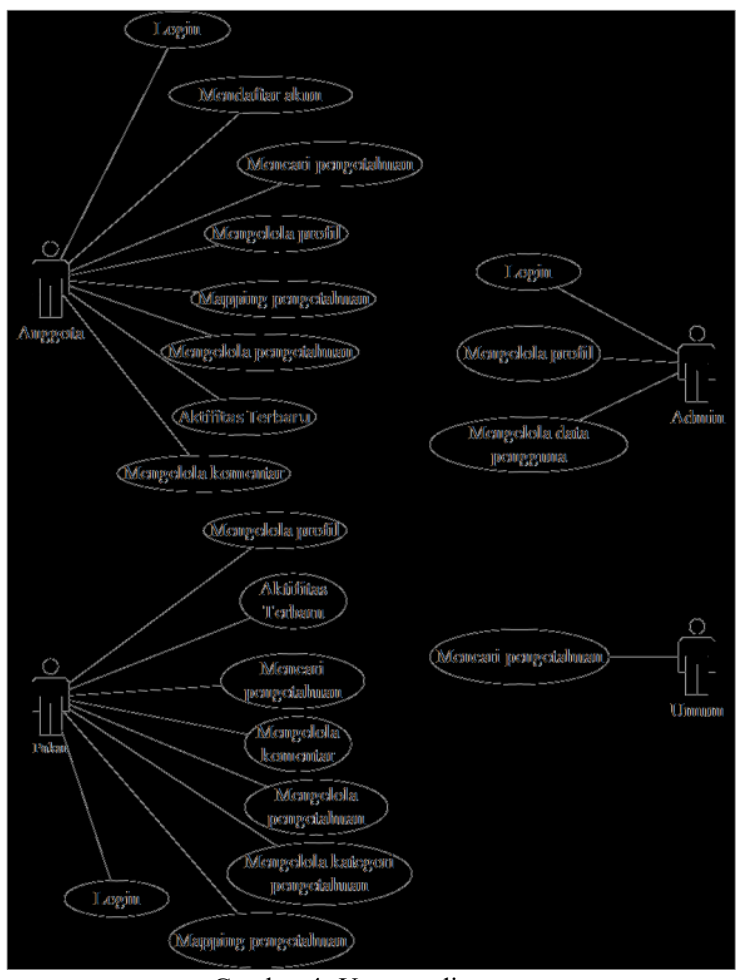

Gambar 4. Usecase diagram

Anggota merupakan aktor yang memiliki delapan fitur yaitu mencari pengetahuan, mengelola profil, mendaftar akun, melihat pembuat pengetahuan, melihat mapping pengetahuan, melihat pengetahuan, melihat aktifitas, dan mengelola komentar. Pakar dapat melakukan seluruh fitur dari anggota ditambah satu fitur yaitu mengelola pengetahuan yang merupakan menambah atau mengubah pengetahuan. Umum merupakan masyarakat umum yang memiliki akses pencarian menerapkan algoritma pencarian dokumen berdasarkan kalimat deskripsi menggunakan vector space model, fitur mengelola komentar sebagai knowledge sharing merupakan sarana berbagi pengalaman antar pengguna melalui komentar pada pengetahuan yang dibaca, dan fitur mengelola pengetahuan sebagai knowledge capture menyediakan sarana berbagi pengetahuan melalui proses menambah pengetahuan baru untuk disimpan dalam sistem.

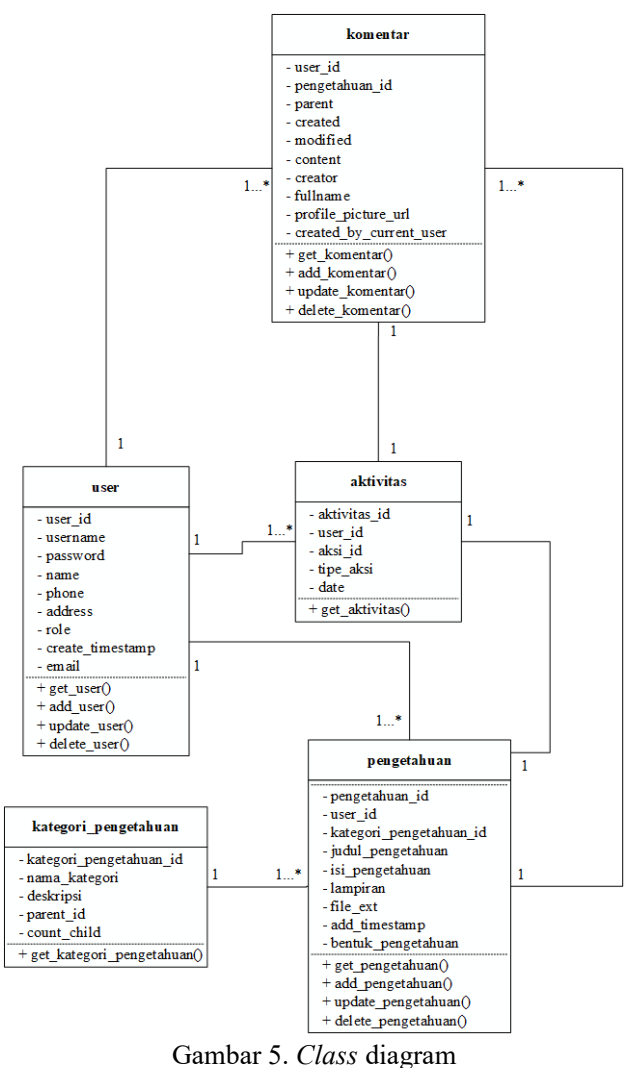


Kemudian dilakukan pembuatan class diagram yang digunakan untuk proses pembuatan database. Terlihat pada Gambar 5 struktur dari class diagram yang memiliki 5 buah class yaitu user, aktifitas, komentar, pengetahuan, dan kategori pengetahuan.

Selanjutnya dilakukan proses implementasi rancangan fungsional menggunakan aplikasi berbasis Web dengan framework codeigniter berbahasa pemrograman PHP. Hasil implementasi sistem untuk fitur mencari pengetahuan yang merepresentasikan knowledge discovery dapat dilihat pada Gambar 6. mengubah pengetahuan yang sudah tersimpan maupun menambahkan pengetahuan baru.

\subsection{Verifikasi dan Validasi Knowledge Management System}

Pengujian logikal meliputi pengujian hasil kodifikasi pengetahuan melalui pakar untuk proses validasi pengetahuan seperti pada Tabel 5 . Terdapat empat kategori pengetahuan yang memiliki pengetahuan berbentuk video maupun dokumen yang telah valid.

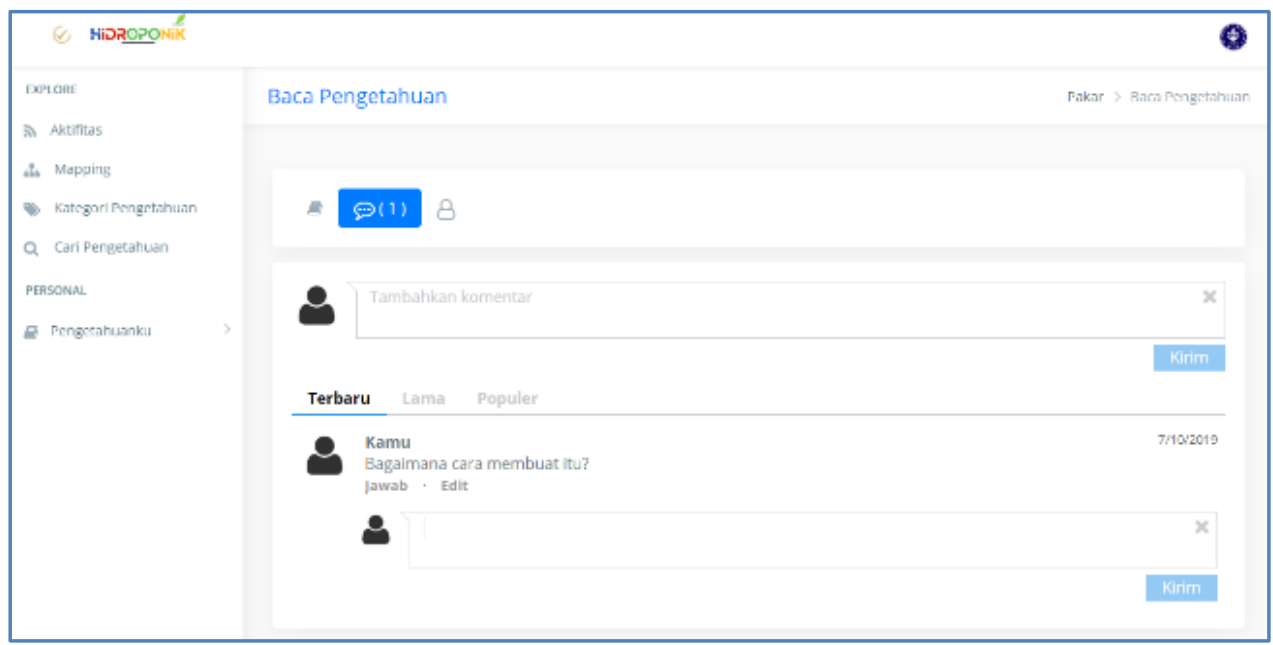

Gambar 7. Halaman mengelola komentar

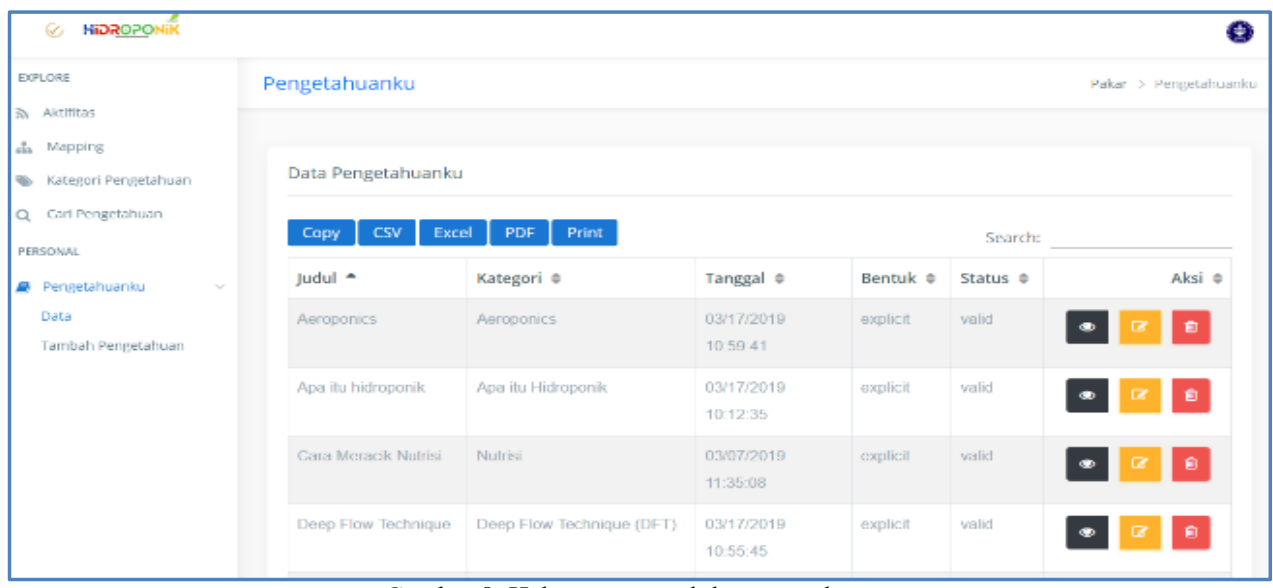

Gambar 8. Halaman mengelola pengetahuan

Pengguna dapat memasukan kata kunci pencarian pengetahuan lalu sistem akan memproses kata kunci dengan menilai kemiripan kata kunci terhadap deskripsi dokumen melalui proses pembobotan dokumen pengetahuan sesuai dengan kata kunci.

Hasil implementasi fitur mengelola komentar yang merepresentasikan knowledge sharing dapat dilihat pada Gambar 7. Pengguna dapat berbagi pengalaman melalui saling berbalas komentar pada pengetahuan yang dibaca.

Fitur mengelola pengetahuan yang merepresantasikan knowledge capture terlihat pada Gambar 8. Pengguna dapat melihat pengetahuan,
Tabel 5. Validasi Pengetahuan

\begin{tabular}{|c|c|c|c|}
\hline No. & Kategori & Pengetahuan & Status \\
\hline 1 & $\begin{array}{l}\text { Pengetahuan } \\
\text { Dasar }\end{array}$ & $\begin{array}{l}\text { Terdapat } 9 \text { video berformat } \\
\text { mp4, } 5 \text { dokumen presentasi } \\
\text { berformat pptx dan } 5 \text { dokumen } \\
\text { berformat pdf }\end{array}$ & Valid \\
\hline 2 & $\begin{array}{l}\text { Hama dan } \\
\text { Penyakit }\end{array}$ & $\begin{array}{l}\text { Terdapat } 1 \text { video berformat } \\
\text { mp4 dan } 2 \text { dokumen berformat } \\
\text { pdf }\end{array}$ & Valid \\
\hline 3 & $\begin{array}{l}\text { Sistem } \\
\text { Hidroponik }\end{array}$ & $\begin{array}{l}\text { Terdapat } 3 \text { video } \text { berformat } \\
\text { mp4 dan } 6 \text { dokumen } \\
\text { berformat pdf }\end{array}$ & Valid \\
\hline 4 & Hasil Panen & $\begin{array}{l}\text { Terdapat } 1 \text { video berformat } \\
\text { mp4 dan } 2 \text { dokumen } \\
\text { berformat pdf }\end{array}$ & Valid \\
\hline
\end{tabular}


Selanjutnya dilakukan pengujian penerimaan pengguna menggunakan blackbox testing dapat dilihat pada Tabel 6. Pengujian berdasarkan fitur utama klasifikasi KMS yang terdiri dari beberapa fungsi yang dihasilkan dari fitur mencari pengetahuan, mengelola pengetahuan, dan mengelola komentar. Hasil blackbox testing menunjukan fitur utama klasifikasi KMS telah berjalan dengan baik.

\begin{tabular}{|c|c|c|c|c|}
\hline Deskripsi & Kondisi & Uji & Hasil & Status \\
\hline $\begin{array}{l}\text { Mencari } \\
\text { pengetahuan }\end{array}$ & $\begin{array}{l}\text { Memilih } \\
\text { menu } \\
\text { cari } \\
\text { pengetah } \\
\text { uan }\end{array}$ & $\begin{array}{l}\text { Mengisi } \\
\text { kata kunci } \\
\text { pencarian }\end{array}$ & $\begin{array}{l}\text { Menampilka } \\
\mathrm{n} \\
\text { pengetahuan } \\
\text { yang dicari }\end{array}$ & Valid \\
\hline $\begin{array}{l}\text { Menambah } \\
\text { pengetahuan }\end{array}$ & $\begin{array}{l}\text { Memilih } \\
\text { menu } \\
\text { pengetah } \\
\text { uan }\end{array}$ & $\begin{array}{l}\text { Menambah } \\
\text { pengetahua } \\
\mathrm{n}\end{array}$ & $\begin{array}{l}\text { Menampilka } \\
\mathrm{n} \\
\text { pengetahuan } \\
\text { yang baru }\end{array}$ & Valid \\
\hline $\begin{array}{l}\text { Mengubah } \\
\text { pengetahuan }\end{array}$ & $\begin{array}{l}\text { Memilih } \\
\text { menu } \\
\text { pengetah } \\
\text { uan }\end{array}$ & $\begin{array}{l}\text { Mengubah } \\
\text { pengetahua } \\
\mathrm{n}\end{array}$ & $\begin{array}{l}\text { Menampilka } \\
\mathrm{n} \text { informasi } \\
\text { pengetahuan } \\
\text { berhasil } \\
\text { diubah }\end{array}$ & Valid \\
\hline $\begin{array}{l}\text { Menghapus } \\
\text { pengetahuan }\end{array}$ & $\begin{array}{l}\text { Memilih } \\
\text { menu } \\
\text { pengetah } \\
\text { uan }\end{array}$ & $\begin{array}{l}\text { Menghapus } \\
\text { pengetahua } \\
\mathrm{n}\end{array}$ & $\begin{array}{l}\text { Menampilka } \\
\mathrm{n} \text { informasi } \\
\text { pengetahuan } \\
\text { berhasil } \\
\text { dihapus }\end{array}$ & Valid \\
\hline $\begin{array}{l}\text { Menambah } \\
\text { komentar }\end{array}$ & $\begin{array}{l}\text { Memili } \\
\mathrm{h} \text { menu } \\
\text { koment } \\
\text { ar }\end{array}$ & $\begin{array}{l}\text { Mengisi } \\
\text { komentar }\end{array}$ & $\begin{array}{l}\text { Menampilk } \\
\text { an } \\
\text { komentar }\end{array}$ & Valid \\
\hline $\begin{array}{l}\text { Mengubah } \\
\text { komentar }\end{array}$ & $\begin{array}{l}\text { Memili } \\
\mathrm{h} \text { menu } \\
\text { koment } \\
\text { ar }\end{array}$ & $\begin{array}{l}\text { Menguba } \\
\mathrm{h} \\
\text { komentar } \\
\text { yang } \\
\text { dipilih }\end{array}$ & $\begin{array}{l}\text { Komentar } \\
\text { baru } \\
\text { ditampilkan }\end{array}$ & Valid \\
\hline $\begin{array}{l}\text { Menghapus } \\
\text { komentar }\end{array}$ & $\begin{array}{l}\text { Memili } \\
\text { h menu } \\
\text { koment } \\
\text { ar }\end{array}$ & $\begin{array}{l}\text { Menghap } \\
\text { us } \\
\text { komentar }\end{array}$ & $\begin{array}{l}\text { Komentar } \\
\text { terhapus } \\
\text { dari menu } \\
\text { komentar }\end{array}$ & Valid \\
\hline
\end{tabular}

\section{KESIMPULAN}

Knowledge management system (KMS) budidaya hidroponik dikembangkan sebagai sarana untuk berbagi pengetahuan yang dapat dimanfaatkan oleh masyarakat. KMS ini sudah berhasil dirancang dan dikembangkan menggunakan pendekatan knowledge management sytem life cycle.

Pada penelitian ini berhasil dikembangkan KMS dengan standar fitur klasifikasi yaitu knowledge capture pada menu mengelola pengetahuan, knowledge sharing pada menu komentar dan knowledge discovery pada menu pencarian pengetahuan yang dapat digunakan untuk mendukung proses pembelajaran digital dalam smart society. Hasil uji coba menunjukkan bahwa fungsi standar klasifikasi KMS sudah terpenuhi dan berfungsi dengan baik.

\section{DAFTAR PUSTAKA}

AWAD, E.M., GHAZIRI, H.M., 2010. Knowledge Management. USA: Prentice Hall.

CHOURABI, H., NAM, T., WALKER S., GILGARCIA, J.R., MELLOULI, S., NAHON, K., PARDO, T.A., SCHOLL, H.J., 2012. Understanding Smart City Initiatives: An Integrative and Comprehensive Theoretical Framework.

CITIASIA (Citiasia Center for Smart Nation)., 2015. Smart Nation: Mastering Nation's Advancement from Smart Readiness to Smart City. Jakarta (ID): Citiasia, Inc.

DISKOMINFOSTANDI (Dinas Komunikasi Informasi dan Persandian Kota Bogor), 2017a. Executive summary master plan smart city Kota Bogor.

DISKOMINFOSTANDI (Dinas Komunikasi Informasi dan Persandian Kota Bogor), 2017b. Buku \#2 master plan smart city Kota Bogor.

DISTANI (Dinas Pertanian Kota Bogor), 2014. Rencana Strategis 2015-2019 Dinas Pertanian Kota Bogor. Bogor: Dinas Pertanian Kota Bogor.

HAJRIC, E., 2018. Knowledge Management System and Pratice: A Theoritical anda Practical Guide for Knowledge Management in Your Organization.

HIDAYATI, O., SIREGAR, H., FALATEHAN, A.F., 2017. Konversi Lahan Sawah di Kota Bogor dan Strategi Anggaran dalam Mengendalikannya.

JIA, Z., LI, D., 2016. An Application of Knowledge Management System for Tzourism Regions. IEEE, pp.1-5.

LEVY, C., WONG, D., 2014. Towards a smart society.

METROPOLITAN., 2018. Kohibora Fokus Hijaukan Kota Bogor Tiap Kecamatan Satu Hidroponik [internet]. [diacu 2019 maret 21]. Tersedia di [http://www.metropolitan.id/2018/11/kohib ora-fokus-hijaukan-kota-bogor-tiapkecamatan-satu-hidroponik/]

MUNIR, N.S., 2011. Penerapan Manajemen Pengetahuan di Perusahaan di Indonesia [internet]. [diacu 2019 maret 21]. Tersedia dari

[http://www.opi.lipi.go.id/data/1228964432 /data/13086710321320825841.makalah.pdf ]

NEGRE, E.L., ROSENTHAL-SABROUX, C.L., GASCO, M., 2015. A knowledge-based conceptual vision of the smart city.

NJERU, J.N., ANAGO, R., BONDARENKO, E., DIARRA, S., 2017. Creating the smart society: Social and economic development throught ICT applications. Ganeva (CH): ITU-D Study Groups. 
SEMERTZAKI, E., 2011. Special Libraries as Knowledge Management Centres. Chandos Publishing.

SWASTIKA, S., YULFIDA, A., SUMITRO, Y., 2017. Buku Petunjuk Teknis Budidaya Sayuran Hidroponik (Bertanam Tanpa Media Tanah). Riau (ID): Balai Pengkajian Teknologi Pertanian (BPTP) Balitbangtan Riau.

ULA, M., SAADAH, AMIIN, M.K., 2015. Sustainable Agriculture System (SAc-S): Inovasi Konsep Pertanian Urban Sebagai Pembangunan Berkelanjutan dan Upaya Penanganan Masalah Perkotaan.

WORLD BANK., 2016. Kisah Perkotaan Di Indonesia. Jakarta (ID). 
Halaman ini sengaja dikosongkan 